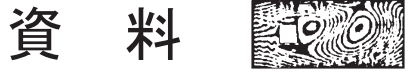

\section{マルチファン型非定常気流風洞装置の紹介 \\ Introduction of Multi-fan Unsteady Flow Wind Tunnel}

\author{
飯田有未*1 \\ 染川大輔* 1 \\ Yumi IIDA \\ Daisuke SOMEKAWA
}

\section{1.はじめに}

建築物の耐風設計は, 建築物の大型化・高層化に伴い設 計過程において重要なウエイトを占めるようになってき た。以来, 風荷重の評価の精緻化・高度化が進められてき ているが，未だに強風イベント発生時の風による被害は 後を絶たない。

建築物の強風被害の中で最も多いものは外装材の被害 である。外装材の被害は, 瞬間的に生じる風圧が原因とな る可能性が指摘されている1が，時間的，空間的に変化の 大きい, 寸なわち非定常な風速変動が外装材の風荷重に 与える影響について検討している研究は少ない。これは 現在一般的に使用されている境界層風洞では，非定常な 風速変動を再現できないことに起因すると思われる。

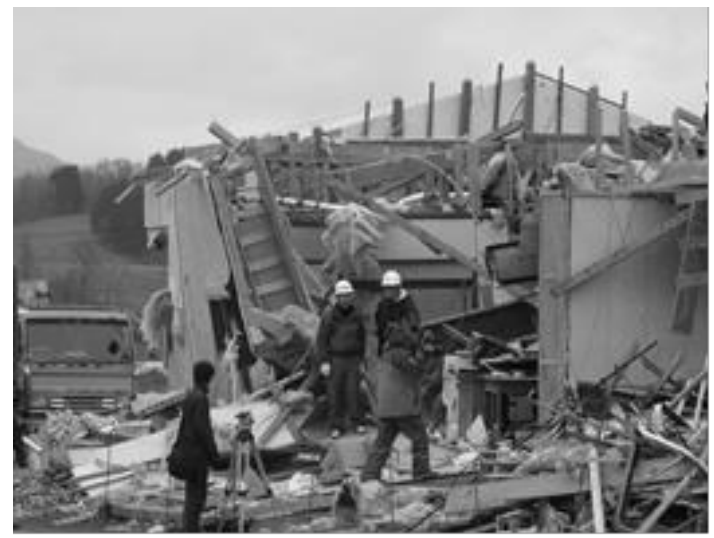

図 1 竜巻による被害(2006 年北海道佐呂間町)
また SNS の浸透によって，竜巻やダウンバーストとい った局地的な突風現象による被害や観測事例が増加して いる(図 1)。たとえば, 2012 年に茨城県つくば市等で発生 した $3 つ の$ 竜巻による災害では死傷者 50 人以上の人的被 害，2000 棟以上の建物被害が生じた ${ }^{2)}$ 。近年では2019年 の千葉県市原市，宮崎県延岡市で台風に伴い生じた竜巻 により構造物に被害が生じている。

こうした状況のもと, 従来の境界層風洞では再現でき ない非定常な風速変動や, 局地的な強風現象を再現寸る ためにエッフェル型の風洞を新設した。本報告では, 新設 した風洞の特徵および性能の概要を報告する。

2. マルチファン型非定常気流風洞装置の概要

2. 1 マルチファン型非定常気流風洞装置

新設した装置は, 時間的・空間的に大きな変化を伴う瞬 間的な風の再現を可能とした「マルチファン風洞装置」, 竜巻状およびダウンバース卜状気流を再現する「竜巻発 生装置」,「ダウンバース卜発生装置」の 3 種類の装置に よって構成され，それらを独立あるいは組み合わせて使 用することができる。総称として「マルチファン型非定常 気流風洞装置」と呼んでいる。装置の概要を図 2 および 図3 亿示す。

風路の断面寸法は $1.5 \mathrm{~m} \times 1.5 \mathrm{~m}$ であり，風路の長さは $10 \mathrm{~m}$ である。風路上部に沿ってレールが設置されており， 竜巻発生装置またはダウンバースト発生装置を取り付け,

* 1 大林組技術研究所研究員 iida.yumi@obayashi.co.jp Technical Research Inst. of Obayashi Corp. 
自走させることが可能である。自走範囲は風路中央から 約 $\pm 3.7 \mathrm{~m}$ の範囲で, 最大 $2 \mathrm{~m} / \mathrm{s}$ の速さで移動する。

2. 2 マルチファン風洞装置

マルチファン風洞装置は複数の小型ファンと風路によ って構成される(図 4, 図 5)。直径 $240 \mathrm{~mm}$ の小型ファン を, 縦方向と横方向に 9 台ずつ, 計 81 台配置している。 小型ファンの制御回転数(以下, ファン回転数)は $0 \sim 50 \mathrm{~Hz}$ であり, 正方向あるいは逆方向に回転することができ, 正 転時の最大風速は約 $10 \mathrm{~m} / \mathrm{s}$ である。各ファンの回転数を それぞれ独立して制御することが可能で，風路内に時間 的・空間的に変化する気流を発生させることができる。

\section{3 竜巻発生装置}

竜巻の風速分布モデルとして一般的なランキン渦モデ ルを再現するアイオワ州立大学の竜巻状気流発生装置 (以下，ISU 型装置 $\left.{ }^{3}\right)$ と同様の機構の装置を導入した。竜 巻発生装置の概観を図 6 (a)に, 本体の断面図と座標軸の 定義を図 7 に示寸。外形と送風機の直径はそれぞれ約 $1.5 \mathrm{~m}, 0.5 \mathrm{~m}$ である。ガイドベーンは 18 枚配置され，0〜 $70^{\circ}$ の範囲で設定可能である。これにより下降流には強 制的に旋回性状が与えられ，その気流をファンによって

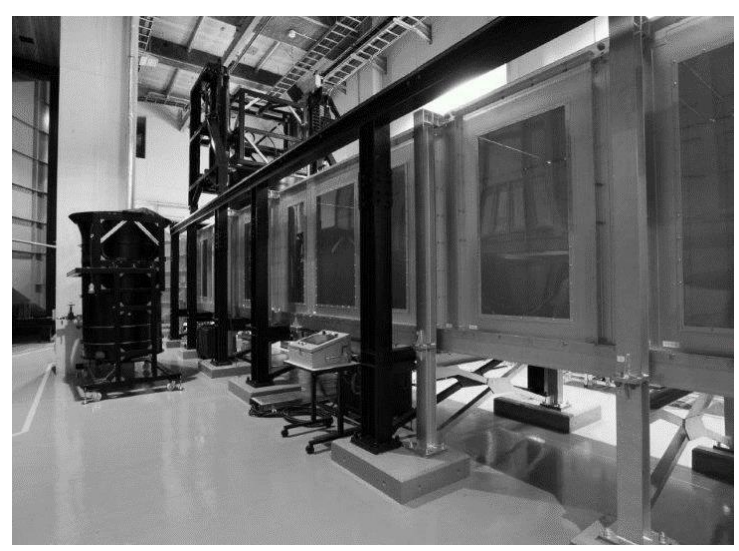

図 2 マルチファン型非定常気流風洞装置
吸い上げることで竜巻状の気流を再現する。吸込口から 床面までの距離である収束層 $h_{0}$ は $175 \mathrm{~mm} \sim 1,860 \mathrm{~m}$ の範 囲である。収束層とは積乱雲直下の地表付近を示し,この 範囲に竜巻が再現される。ファンの回転数は 1 3,000rpm の範囲で変えることができる。最大風速は約 $10 \mathrm{~m} / \mathrm{s}$ であ る。なお, 本装置によって縮尺率 $1 / 100$ 程度の竜巻を再現 できる。また検討の対象とする竜巻の風速は最大風速 $80 \mathrm{~m} / \mathrm{s}$ 程度(藤田スケール 3 程度)を想定している。

2. 4 ダウンバースト発生装置

ダウンバースト発生装置の概観を図 6 (b)に，本体の断 面図と座標軸の定義を図 8 に示す。ファンによる強い気 流が送風口から吹き降万され, 風路の床面に衝突するこ とで, 地表に衝突するダウンバーストの下降噴流が模擬 される。送風口の直径は $1 \mathrm{~m}$ である。ファンの回転数は 1 2000rpm の範囲で, 送風口から床面までの距離は $10 \mathrm{~mm}$ から $1,883 \mathrm{~mm}$ まで変えることができる。最大風速は約 $10 \mathrm{~m} / \mathrm{s}$ である。なお，本装置によって縮尺率 $1 / 1000$ 程度 のダウンバーストを再現できる。また検討の対象とする ダウンバーストの風速は最大風速 $66 \mathrm{~m} / \mathrm{s}$ 程度(藤田スケー ル2程度)を想定している。

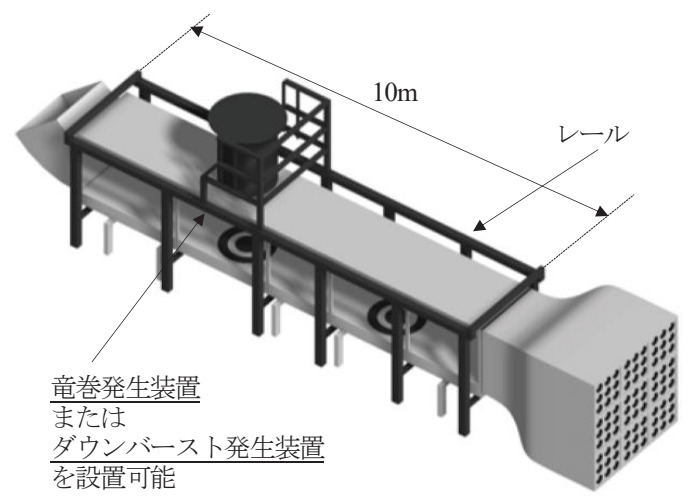

図 3 マルチファン型非定常気流風洞装置

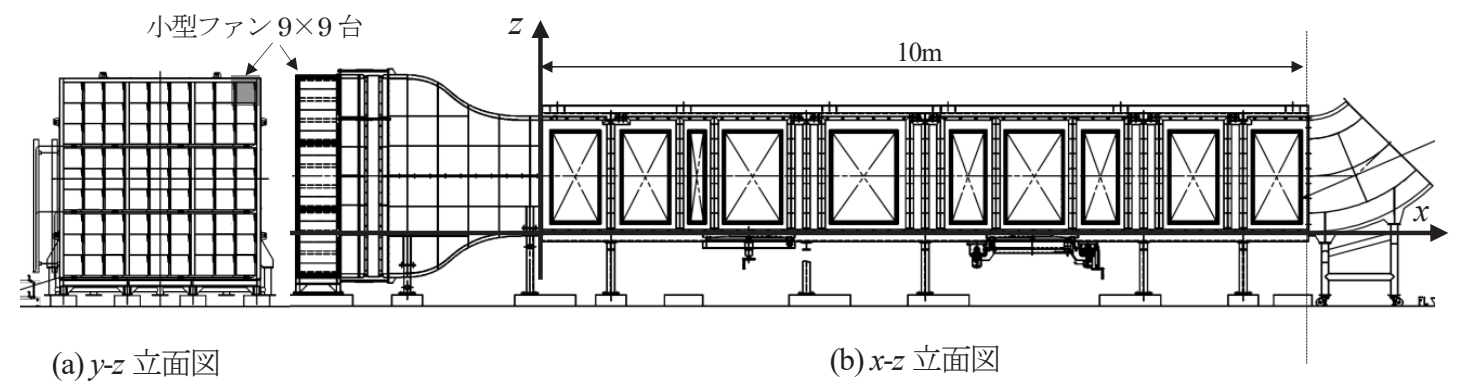

図4 マルチファン風洞装置 立面図 


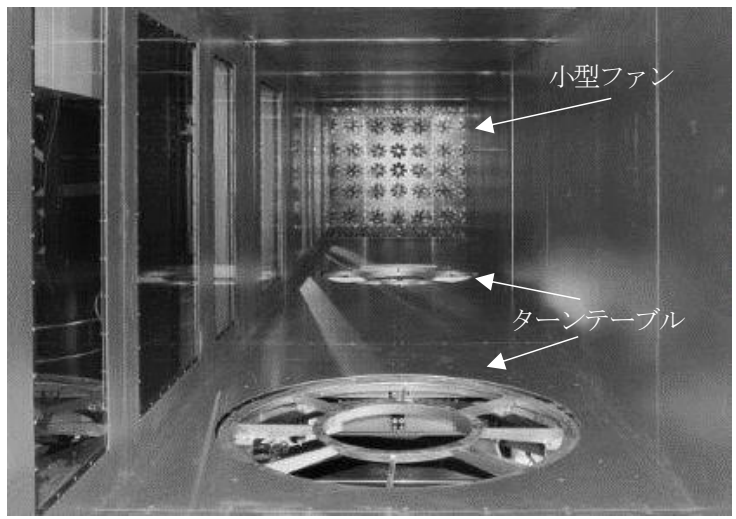

図 5 マルチファン風洞装置

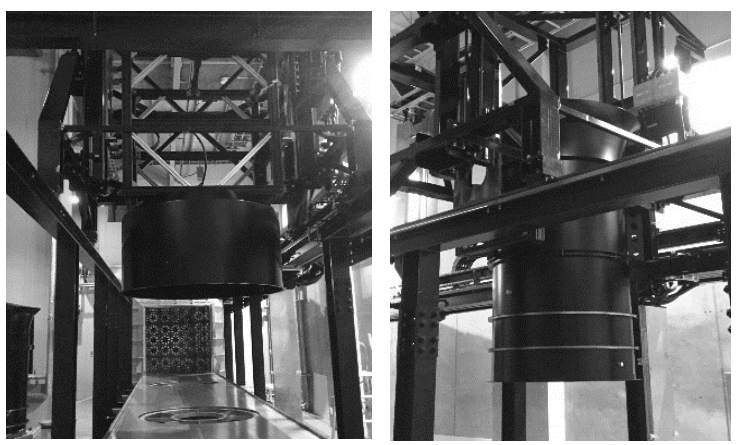

（a）竜巻発生装置 (b) ダウンバースト発生装置 図 6 竜巻・ダウンバースト発生装置

3. 実験装置の性能

3. 1 マルチファンによる風速変動

(1) 実験概要

装置の構成要素の一つであるマルチファンによる風速 変動の再現性を確認するため, ファンの回転数を正弦波 状に変化させ，風速測定を行った。

熱線風速計(I 型プローブ)を用い, 風路の風上端部を $x$ $=0$ (図 4) として $x=2,700 \mathrm{~mm}$, 高さ $200 \mathrm{~mm}$ の位置で測定 した。ファンの回転数は周期 4 秒で $0 \sim 50 \mathrm{~Hz}$ の範囲で変 化させ，サンプリング周波数は $500 \mathrm{~Hz}$ ，計測時間は 60 秒 とした。

\section{(2) 実験結果}

風速とファンの回転数の出力值の時系列データを図 9 に示す。得られた風速は, $0 \mathrm{~m} / \mathrm{s}$ まで下がることはないが, ファン回転数の増加・減少に概ね追従する結果となった。 風速とファン回転数の時系列データの無次元パワースペ クトル密度を図 10 に示す。どちらのピークも $0.25 \mathrm{~Hz}$ 付 近で生じており, この周期での風速変動をマルチファン により再現できることが確認できた。

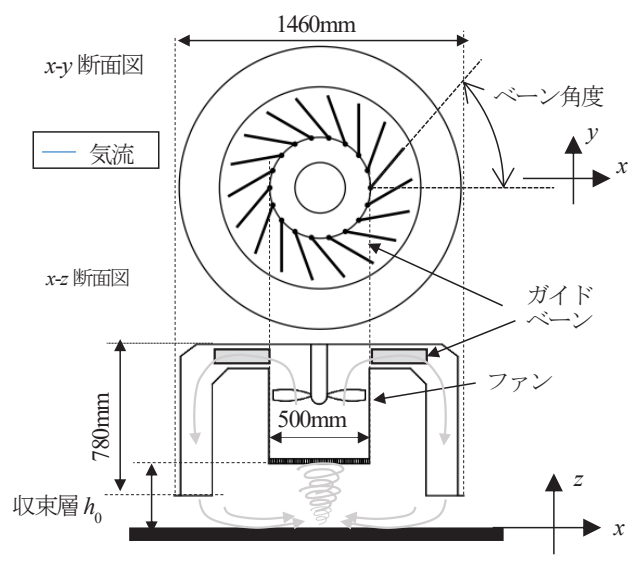

図 7 竜巻発生装置 断面図

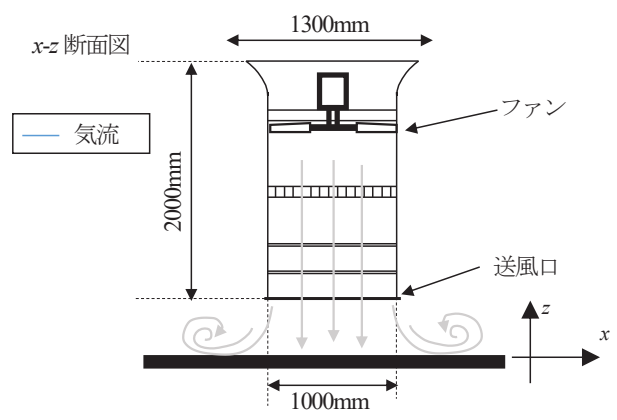

図 8 ダウンバースト発生装置 断面図

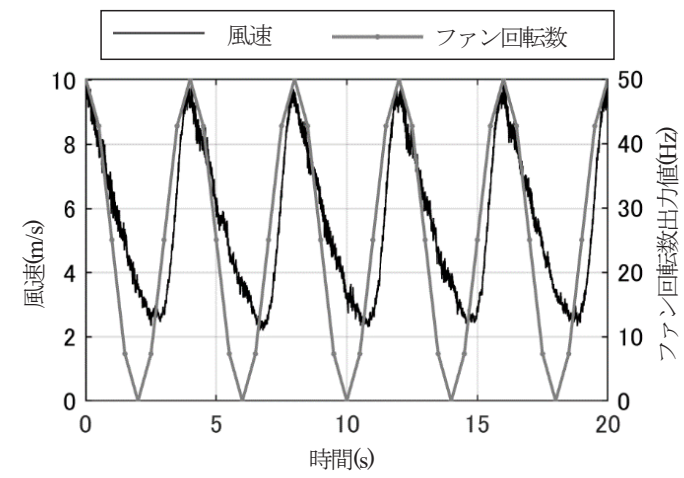

図 9 風速とファン回転数出力值の時系列データ

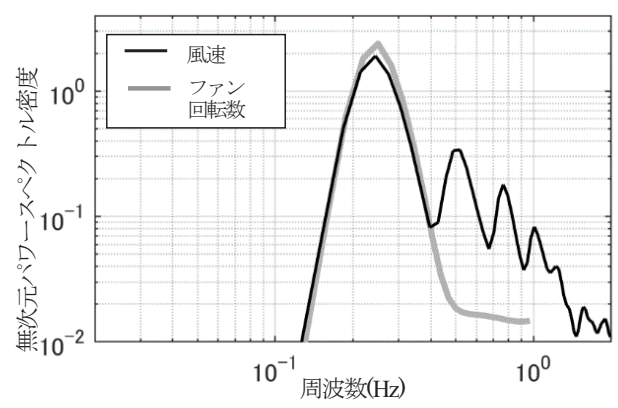

図 10 無次元パワースペクトル密度 
3. 2 竜巻状気流の風速測定

(1) PIV について

一般に気流の測定に用いられる熱線風速計は測定でき る風向が限定されるため, 風向変化が大きい竜巻状気流 の測定は難しい。そこで， 3 次元 PIV(Particle Image Velocimetry，散布された微細泡の動きの可視化により風 速を測る装置)を導入した。へリウムガスを含むバブルを 発生させる粒子発生装置, 光源となる LED ライトと 4 台 のハイスピードカメラを図 11 および図 12 に示す位置に 設置し測定を行った。撮影は解像度 $1,024 \times 1,024$ pixel で 行い，可視化範囲は図 11 の斜線の範囲とした。これによ り, 最小で $0.6 \mathrm{~mm}$ 毎(1pixel あたり $0.6 \mathrm{~mm}$ 程度)に風速値 を得ることができる。

\section{(2) 実験概要}

竜巻発生装置はガイドベーンを $50^{\circ}$, 収束層 $h_{0}$ を $600 \mathrm{~mm}$ と設定した。装置内のファン回転数は $1,000 \mathrm{~Hz}$ と した。測定における $x, y, z$ 軸の定義を図 11 に示す $(z$ 軸 は紙面の手前向き $)$ ここでは竜巻装置中央位置を $(x, y)=(0$, 0) とし， $x, y, z$ 軸方向の風速成分をそれぞれ $u, v, w$ と する。サンプリング周波数を $2 \mathrm{kHz}$ とし 4,000 枚の画像(2 秒間)を取得した。これを 3 セット行った。

\section{(3) 実験結果}

PIV で得られた各粒子の動きと移動速度のスナップシ ヨットを図 13 に示す。粒子群の輪郭が漏斗状の形状とな っている様子が 3 次元的にとらえられており, 各粒子の 風速と風向もあわせて取得することができた。

得られた風速比(接線風速/最大接線風速)について既 往の実験および野外観測值 ${ }^{4), 5)}$ との比較を図 14 に示す。

ここで示寸結果は3セットのアンサンブル平均值であり, $y=0 \mathrm{~mm}$ (竜巻中央部), $z=50 \mathrm{~mm} の x$ 軸上の平均速分布を 示している。縦軸は接線風速の最大值, 横軸は竜巻中心か ら最大風速発生位置までの距離 $R_{\max }$ で無次元化してある。 なお, 本実験の $R_{\text {max }}$ は約 $100 \mathrm{~mm}$ である。PIV で得られた 竜巻状気流の風速比は，既往の研究の竜巻装置および実 測による風速比とよく一致している。

平均風速の $y=0 \mathrm{~mm}$ (竜巻中央部)における $x-z$ 断面分 布を図 15 に示す。風速 $v$ では $x=-100 \mathrm{~mm}$ と $100 \mathrm{~mm}$ 付 近に最小(負值) ・最大(正值)風速が生じており, 気流が上 から見て反時計回りに旋回していることが分かる。風速 $w$ では同じ $x=-100 \mathrm{~mm}, 100 \mathrm{~mm}$ の位置で上昇気流が見ら れた。これは竜巻に類似した旋回上昇気流を表しており, 旋回流の中心付近では弱い下降気流となっていることな ど, 竜巻に見られる特徵が表れている。以上より本装置に よって竜巻状の旋回流が再現できると言える。

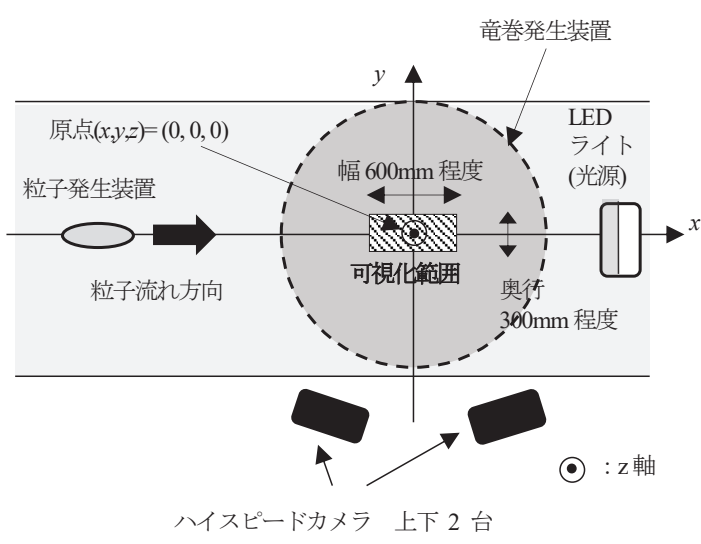

図 11 PIV 計測状況

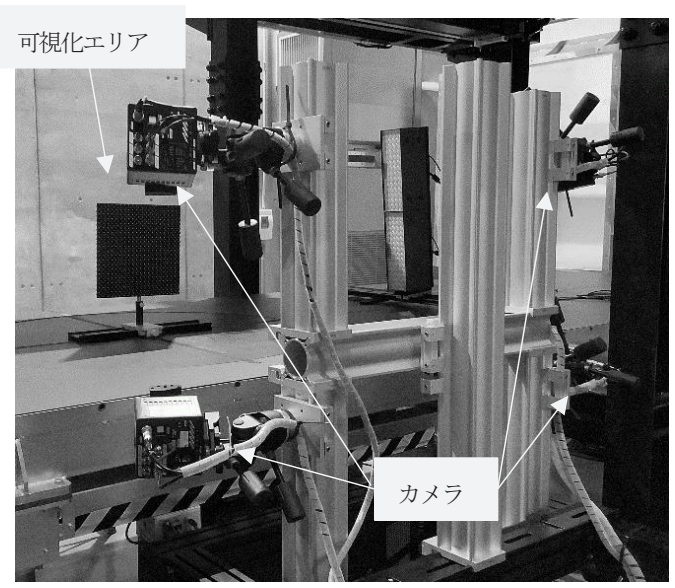

図 12 ハイスピードカメラの設置状況

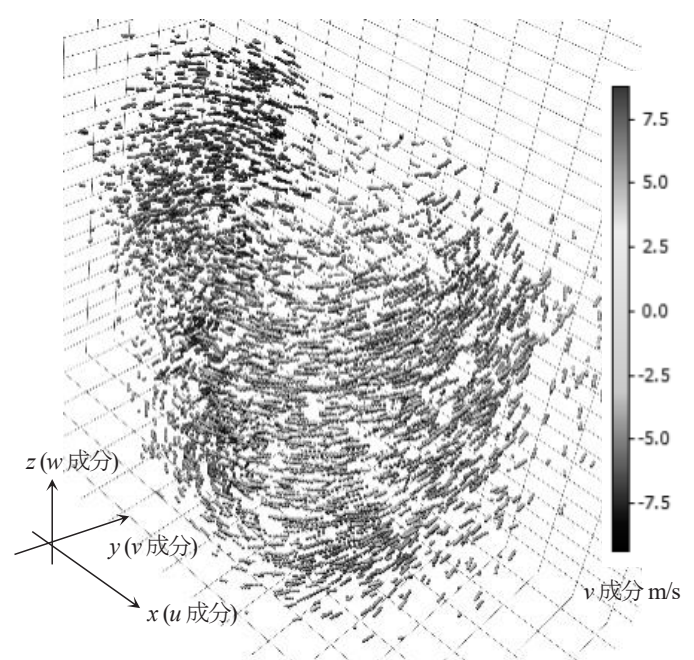

図 13 PIV による風速計測結果の スナップショット 

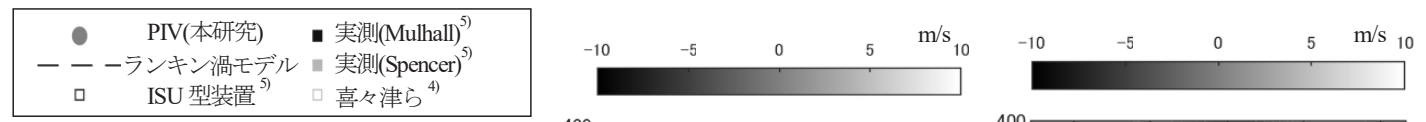

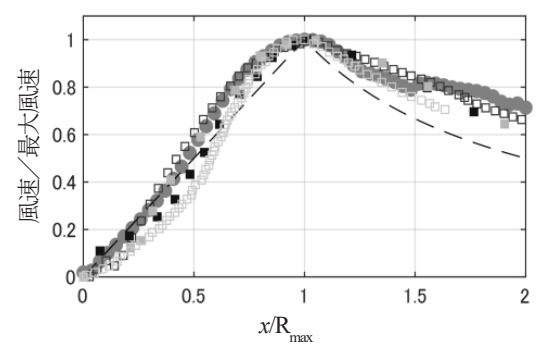

図 14 既往の実験・実測の風速比との比較

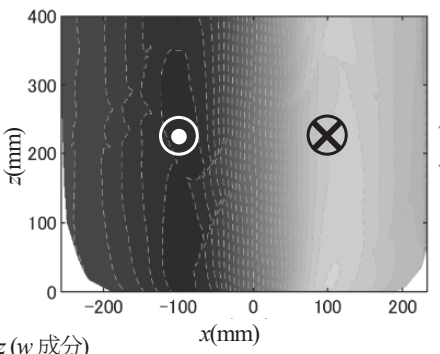

(a) $v$

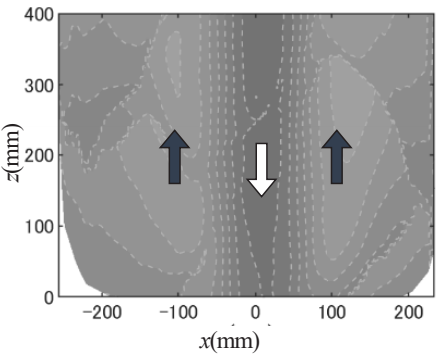

(b) $w$

図 15 平均風速分布 $(x-\mathrm{z}$ 断面 $)$

\section{4.おおりに}

今回新設した「マルチファン型非定常気流風洞装置」に ついて, 装置の概要と基本的な性能確認のための実験結 果について報告した。

この装置の導入によって，これまで実験的な検証が難 しかった風向・風速が変化する現象などについて検討し ていくことが可能になっただけでなく， 3 次元の PIVを 併用することで数值解析によって得られた風速分布の比 較が可能となった。これにより, 数值解析技術の向上にも 寄与できるものと考えている。そうした成果によって, 強 風による被害低減につなげていきたいと考えている。

最後に, 本装置の計画にあたり, 貴重なご助言を頂いた 宮崎大学の宮城弘守助教, 国土技術政策総合研究所の 喜々津仁密氏に厚く御礼申し上げます。

\section{参考文献}

1) 喜多村 美保, 友清 衣利子, 前田 潤滋, 「構造物被害
に及ぼす風速変動特性の影響」, 第18回風工学シンポ ジウム論文集, pp 187-192, (2004)

2) 気象庁，「竜巻等の突風データベース」, http://www.data.jma.go.jp/obd/stats/data/bosai/tornado/, (2020.10)

3) F. Haan, P. Sarkar, W. Gallus., "Design, construction and performance of a large tornado simulator for wind engineering applications", Engineering Structures, Vol. 30, Issue. 4, pp. 1146-1159, (2008)

4) 喜々津 仁密, 奥田 泰雄, 河井 宏允, 神田 順, 「竜巻 通過時に低層建築物に作用する風力特性に関する実 験的研究」, 第22回風工学シンポジウム論文集, pp 209-214, (2012)

5) H. Hu, Z. Yang, P. Sarkar, F. Haan, "Characterization of the wind loads and flow fields around a gable-roof building model in tornado-like winds", Experiments in Fluids 51(3), pp 835-851, (2011) 